UDC 336.71

JEL Classification: G21, G28

DOI: 10.15587/2706-5448.2021.225700 Article type «Reports on Research Projects»

\section{Roman Stadniychuk}

\title{
ASSESSMENT OF THE CURRENT STATE OF THE USE OF NON-MONETARY METHODS OF STATE REGULATION OF FINANCIAL RECOVERY OF BANKS
}

The object of research is the processes of state regulation of financial recovery of banks by non-monetary methods. One of the most problematic areas is determining the practical aspects of regulating the financial recovery of banks by non-monetary methods, which include:

- establishment of mandatory requirements for banking services and business processes;

- carrying out checks and taking measures in the event of a violation;

- establishment of methods of organizing or conducting banking activities in the process of financial recovery;

- licensing rules. An important aspect is the identification of factors that exacerbate the problems of the banking system, in particular, lead to large-scale lending to related parties; opaque ownership structure; inaccurate financial statements; fictitious accounts in foreign banks; money laundering and the like. Improvement of state regulation of financial recovery of banks through the use of preventive measures is possible with the effective use of non-monetary methods of such regulation.

The study used methods of analysis and synthesis, induction and deduction, methods of systematization and comparison, tabular and graphical methods. The composition of monetary instruments and their features have been determined. The proposed measures for non-monetary regulation of financial recovery of banks are related to:

- improving the procedure for disclosing information on the ultimate owners of the bank;

- strengthening the responsibility of banks for the results of their activities;

- improving the mechanisms for minimizing credit risks for banks both at the stage of issuing a loan and at the stage of its servicing;

- improving the procedure for financial restructuring of problem assets of banks;

- set of recreational measures to restore the bank's solvency, prevent bankruptcy or increase its competitiveness.

The use of non-monetary methods of financial recovery and the introduction of the requirements of European legislation into national banking practice testifies to the improvement of state regulation of financial recovery of banks, protects them from insolvency and ensures development.

Keywords: financial recovery of banks, state regulation methods, central bank, mechanisms of non-monetary regulation measures.

\section{Introduction}

In modern conditions of development of the national economy, an important role is assigned to a stable banking system, which is designed to create a powerful incentive to revive the economic growth of any country through:

- stable functioning of the payment system;

- stimulating investment in the economy and savings; - assistance in the development of financial intermediation and the like.

In the conditions of the financial and economic crisis, the problem of ensuring the reliability of banking institutions is the most acute, and its solution prompts the search for ways to improve them. In such a situation, an important issue is state regulation of financial recovery based on the use of effective and efficient methods and modern approaches, the main goal of which is to ensure public confidence in domestic banks and to prevent the crisis of the entire banking system. Indeed, such an unstable period of insolvency or even liquidation of banks can lead not only to economic and financial challenges, but also to significant social upheavals. Therefore, improving the methods of state regulation of banks' activities is one of the ways to ensure the financial «health» of the banking sector as a whole.

Of particular relevance and importance is the study of issues of state regulation of financial recovery of banks. This is due to the gradual transition to international rules and standards, primarily the introduction of new conceptual standards for banking supervision - Basel II. The organi- 
zation of banking supervision also needs to be improved based on the best international practice.

The experience of foreign banks indicates that the most common measures for the financial recovery of banks are the restructuring of loans during a crisis. It was carried out by repurchasing problem loans, extending credit terms and lowering interest rates. At the same time, among all types of credit loans, first of all, mortgage loans were subjected to restructuring, since they occupy a significant share in the loan portfolio of banks. During the global financial crisis, states created special programs to free leading banks from problem assets. In the event of massive cases of deterioration in the solvency of banking institutions in world practice, it is quite common to create corporations for managing problem assets (USA, Japan, Czech Republic, Sweden, China, Malaysia, etc.). The main goal of such organizations is to buy out problem loans from insolvent banks by selling such assets at the maximum price [1].

At the same time, the use of foreign experience requires taking into account the realities of the national financial and banking system. For example, for Ukraine, the experience of national regulators (the National Bank of Ukraine), obtained in the context of a systemic financial crisis, indicates that due to the action of various factors in the process of working with problem banks and the withdrawal of insolvent banks from the market, it was not always possible to ensure the restoration of the solvency of a banking institution and efficiency of activities. This all confirms the need to take preventive measures that are directly related to non-monetary methods of regulating the financial recovery of banks.

Research and analysis of the main trends in the development of the system of state regulation of financial recovery of banks is the object of close attention of many studies [1, 2]. This is explained by the relevance and importance of this direction in the context of ensuring financial stability of the entire national economy [3, 4]. In particular, aspects of «cleaning» the banking system are highlighted in the works [5, 6]. Methodological aspects of financial recovery of the banking sector are at the center of research of many specialists, for example, in [7-9].

Thus, the object of research is the processes of state regulation of financial recovery of banks by non-monetary methods. The aim of research is to assess the current state of the use of non-monetary methods of state regulation of financial recovery of banks.

\section{Methods of research}

The following scientific methods are used:

- analysis method - when studying theoretical approaches to disclosing the essence of non-monetary methods and provisions of the legislative framework; - comparison method - when determining the specifics of the implementation of financial restructuring procedures and the algorithm for withdrawing banks from the market by various institutions;

- generalization method - when studying the experience of using non-monetary methods, etc.

\section{Research results and discussion}

The beginning of a new wave of the financial and economic crisis in 2014 in Ukraine stimulated increased attention to effective mechanisms to stabilize the country's economy in general and the banking sector in particular. This is what the National Bank of Ukraine (NBU) is called upon to do as the main regulator of the country's financial sector, in order not only to support, but also to increase public confidence in the financial market of the state. At the same time, since 2014, the lexicon of the business elite and citizens includes such terms as «bank insolvency», «temporary administration», «bank liquidation procedure», «payment of guaranteed compensation to bank depositors» and others. At the same time, the work in Ukraine of a previously imperceptible authority, the Fund for Guaranteeing Deposits of Individuals, has intensified. So, starting from 2014 and until 2019, more than half of domestic banks were withdrawn from the market. The history of the termination of each of them is different. Some banks closed on their own, realizing their inability to withstand the economic crisis. Others were driven to a state of insolvency by the owners themselves, transferring all bank assets to their shell companies through opaque schemes. On the whole, stable, with a large authorized capital, protected loan portfolios, banks were withdrawn from the market as insolvent by the decision of the National Bank of Ukraine. At the same time, in connection with the cyclical development of the economy and the phases of the life cycle of business entities, the issues of financial recovery of their time arise for each bank, taking into account the requirements of regulatory norms. Each of the options for realizing the life cycle curve has its own characteristics and is considered individually $[8,9]$.

For financial recovery, it is necessary to competently manage the activities of a banking institution. It is timely assessment, effective prevention, as well as the adoption of balanced and effective management decisions that are the most important means of ensuring the conditions for overcoming the crisis. The effectiveness of the financial recovery of the bank as a whole largely depends on the ability of the management to develop such a business development strategy that would allow achieving the desired results while optimizing the existing risks. The financial recovery strategy of the bank is considered as a complex of remedial measures to restore the bank's solvency, prevent bankruptcy or increase its competitiveness. It provides for the development and implementation of a comprehensive program for its recovery and development. In turn, it contains a system of measures aimed at identifying and eliminating ineffective structural elements and zones, searching for and using hidden reserves and additional incentives in the bank's activities. In general, the strategic approach to financial recovery provides for the development and implementation of a set of interrelated tasks to ensure the optimal use of the financial potential of the bank.

Financial recovery of a banking institution as a process includes:

- first, overcoming problems (and the reasons for their occurrence);

- secondly, the restoration of normal, stable work.

Only if necessary, recovery can contain a reorganization component, in particular, a change in the bank's structure, form of ownership, policy in the field of active and passive operations, capitalization, risk management, etc.

It is advisable to single out two areas of state regulation of financial recovery of banks in Ukraine:

1) monetary regulation, covers economic aspects that directly affect the decision;

2) non-monetary regulation, covers social and administrative aspects. 
Monetary regulation of the financial recovery of banks is aimed at creating economic mechanisms, which are used primarily as a reaction to external factors affecting the banking system as a whole. However, in Ukraine, the range of methods of monetary regulation is very limited. The classic set of monetary policy instruments includes interest rates, open market operations, and required reserve ratios for banks. Usually, the National Bank of Ukraine today uses the first two instruments from the classic set for monetary regulation of financial recovery of banks.

Non-monetary regulation of financial recovery of banks is usually aimed at influencing the activities of banks by establishing mandatory requirements for banking services and business processes, rules for conducting banking activities, conducting checks on their compliance and taking action in case of violations. Methods of non-monetary regulation of the financial recovery of banks relate to the methods of conducting banking activities, the establishment of licensing requirements, restrictions on the implementation of certain types of banking activities, and the main elements of such regulation are control and supervision over the activities of banks.

As part of this work, let's consider in more detail nonmonetary regulation, since the methods of non-monetary state regulation of financial recovery of banks have a significant impact on strengthening the banking system as a whole. The key priorities of the National Bank of Ukraine in this direction are determined:

- introduction of legislative changes to simplify lending. Assisting in the adoption and implementation of legislative changes to develop the secondary market for non-performing loans (NPL);

- opening an international depository Euroclear of an account with the depository of the National Bank. This measure is aimed at facilitating the access of foreign investors to government securities in the national currency, which, in turn, will generate funds, including for refinancing banks for the purpose of their financial recovery; - steady decrease in inflationary pressure and, as a consequence, a decrease in the discount rate. Due to macroeconomic stabilization, it is envisaged to increase the interest of investors in financial instruments in the national currency.

In the banking sector, such measures of non-monetary regulation of financial recovery of banks can be used (Fig. 1).

Such actions of the regulator should ensure a stable, transparent and efficiently functioning banking system. This can be confirmed by the results of the activities of Ukrainian banks in 2019, in which not a single bank was withdrawn from the banking sector due to insolvency, and 70 of 75 operating banks were profitable [10].

The impact of global economic imbalances, the devastating consequences of the crisis, military conflicts in eastern Ukraine are factors that exacerbate the problems of the banking system, in particular, lead to:

- large-scale lending to related parties;

- non-transparent ownership structure;
- inaccurate financial statements;

- fictitious accounts in foreign banks;

- money laundering and the like.

Under such conditions, «laundry banks», «vacuum cleaners», «zombie banks» are actively operating on the market, and «baby boomers» are created for profitable sale. All of them are de facto already considered bankrupt, but they are supported «artificially».

The algorithm for withdrawing an insolvent bank from the market is as follows (Table 1).

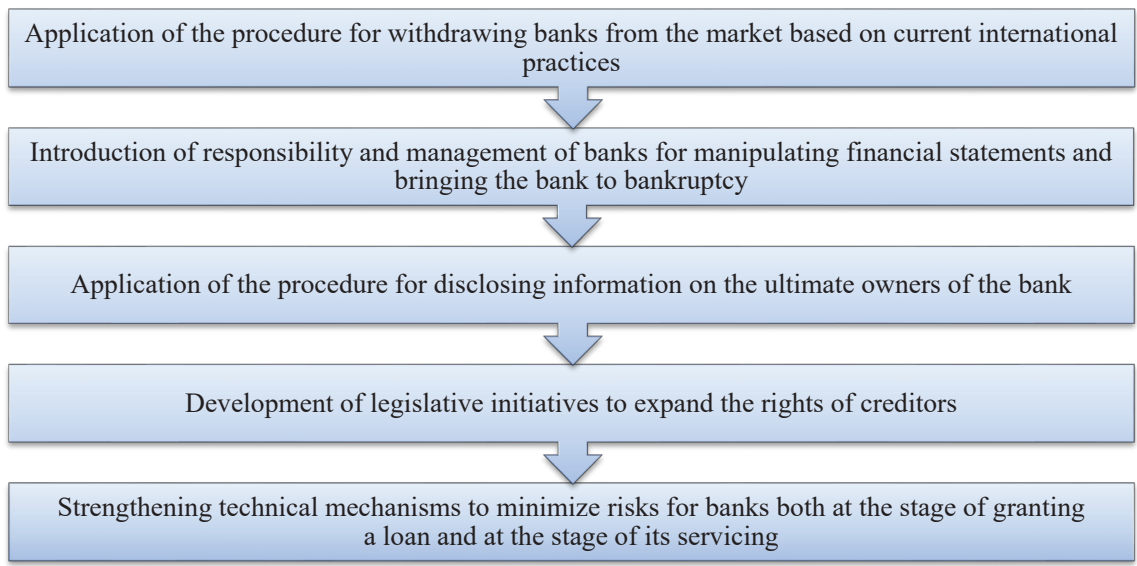
a loan and at the stage of its servicing

In order to improve the situation, regulators, when developing the procedure for withdrawing banks from the market, should take into account current international practices. Let's believe that the goal of state regulation of the financial recovery of banks should not be to withdraw them from the market, but to ensure the stable functioning of banks and the banking system as a whole. Therefore, an important role should be played by the assessment of the stability of banks, which is carried out by the regulator in the person of the National Bank and, on a negative result, the banks for which the need for capital is determined, the regulator puts forward a requirement to develop a capitalization program and/or a restructuring plan. In response to such a requirement, the bank must submit to the regulator a capitalization program for the amount of the need (lack) in capital. In this case, the required amount of additional capitalization is determined by the larger of the two amounts determined:

1) based on the results of assessing the quality of the bank's assets and acceptable collateral for credit operations;

2) projected amount of the need (lack) in capital, determined by the regulator according to the basic macroeconomic scenario for 2018

Non-monetary regulation of the financial recovery of banks is associated with the improvement of the procedure for disclosing information about the ultimate owners of the bank in order to ensure the transparency of its activities. In this direction, the NBU, as the main regulator, carried out a number of measures, which made it possible to disclose information about all bank owners, their significant participation, ownership structure and the nature of relationships. This allows the regulator to effectively influence negative processes in the activities of banks and introduce health-improving procedures. 
Algorithm for withdrawing an insolvent bank from the market in Ukraine

\begin{tabular}{|c|c|c|c|c|c|}
\hline Objects & $\begin{array}{l}\text { Business normal phase } \\
\text { of the bank }\end{array}$ & $\begin{array}{l}\text { Bank deteriora- } \\
\text { tion phase }\end{array}$ & Bank recovery phase & $\begin{array}{l}\text { The phase of classifying the } \\
\text { bank as problematic }\end{array}$ & Bank insolvency phase \\
\hline \multicolumn{6}{|c|}{ Bank } \\
\hline 1 & $\begin{array}{l}\text { Compliance with stan- } \\
\text { dards, high quality of as- } \\
\text { sets, availability of internal } \\
\text { control, risk management } \\
\text { and/or reporting systems }\end{array}$ & $\begin{array}{l}\text { Slowdown of capi- } \\
\text { tal, liquidity, pro- } \\
\text { fitability indicators }\end{array}$ & $\begin{array}{l}\text { Violation of the require- } \\
\text { ments of the legislation on } \\
\text { banking activities, involve- } \\
\text { ment in money laundering, } \\
\text { proliferation of weapons of } \\
\text { mass destruction or terrorist } \\
\text { financing }\end{array}$ & $\begin{array}{l}\text { Violation of capital/liquidity stan- } \\
\text { dards, significant deterioration of } \\
\text { asset quality, violations in the } \\
\text { field of money laundering, lack } \\
\text { of internal control, risk manage- } \\
\text { ment and/or reporting systems }\end{array}$ & $\begin{array}{l}\text { The value of assets is lower than the } \\
\text { value of liabilities. Regulatory capital } \\
\text { is less than } 1 / 3 \text { of the minimum } \\
\text { payment }\end{array}$ \\
\hline \multicolumn{6}{|c|}{ National Bank of Ukraine (NBU) } \\
\hline 2 & $\begin{array}{l}\text { Reporting. } \\
\text { Supervisory activities. } \\
\text { Stress testing and asset } \\
\text { quality assessment }\end{array}$ & $\begin{array}{l}\text { Enhanced supervis } \\
\text { curator. Restrictior }\end{array}$ & $\begin{array}{l}\text { sion. A special control mode - } \\
\text { n of activity }\end{array}$ & $\begin{array}{l}\text { Solvency recovery plan. Prohi- } \\
\text { bition of transactions on cor- } \\
\text { respondent accounts. Curator: } \\
\text { monitoring and reporting }\end{array}$ & $\begin{array}{l}\text { Decision to classify the bank as in- } \\
\text { solvent (maximum } 30 \text { days) }\end{array}$ \\
\hline \multicolumn{6}{|c|}{ Deposit Guarantee Fund for Individuals (DGFI) } \\
\hline 3 & Absent & $\begin{array}{l}\text { Prohibition of the } \\
\text { moval of the ban } \\
\text { a meeting of shar } \\
\text { as problematic }\end{array}$ & $\begin{array}{l}\text { payment of dividends. Re- } \\
\text { k's management. Convening } \\
\text { reholders. Bank classification }\end{array}$ & $\begin{array}{l}\text { Inspection. Data pгеparation and } \\
\text { evaluation }\end{array}$ & $\begin{array}{l}\text { 1. Provisional administration (maxi- } \\
\text { mum } 30 \text { days). } \\
\text { 2. Implementation of the insolvency } \\
\text { resolution plan: } \\
\text { - sale of a bank/sale of property; } \\
\text { - transitional bank, nationalization } \\
\text { or liquidation and revocation of the } \\
\text { NBU license (at the DGFI request) }\end{array}$ \\
\hline
\end{tabular}

Note: author's development based on $[10,11]$

As a measure of non-monetary regulation of the financial recovery of banks, the issue of responsibility and top management of banks, as well as other financial institutions, has become an acute agenda in many countries of the world at different times. For the United States and the countries of the European Union, this issue has acquired particular importance in the light of the 2008 financial crisis, when the leading investment banks - Bear Stearns, Lehman Brothers, Merrill Lynch and others - failed to fulfill their obligations to creditors [12].

Legislative regulation of bringing to property liability persons associated with an insolvent bank was introduced in Ukraine in 2015 in accordance with Art. 52 of the Law of Ukraine «On the system of guaranteeing deposits of individuals». In addition to strengthening the responsibility of its managers and owners, they have expanded the circle of persons who can be brought to administrative and criminal liability, including persons associated with the bank.

An important aspect of non-monetary regulation of financial recovery of banks is the implementation of procedures and the use of measures of mechanisms in order to minimize the risks of banks associated with lending operations, since during the crisis, significant volumes of outstanding loans accumulated in banks, which negatively affected their solvency. Now the measures applied by the NBU to resolve problem debts did not give the expected results. These gaps are somewhat eliminated by the Law of Ukraine «On Amendments to Certain Laws of Ukraine Regarding Improving the Procedure for Financial Restructuring» [13], which entered into force on September 25, 2019. It introduced a joint financial restructuring procedure for several debtors who are related parties, but have different (incompatible) creditors. According to this Law, the debtor will continue to be a legal entity, one or more debtors, which, at the request of the creditor, can be combined in one general procedure. Regarding the procedure for financial restructuring, it is not simple and has certain features concerning the main stages of the financial restructuring of the debtor in accordance with the legislative changes introduced (Table 2).

Table 2

Comparative characteristics of the main stages of financial restructuring in accordance with the terms of the Law and without the law

\begin{tabular}{|c|l|c|c|}
\hline No. & \multicolumn{1}{|c|}{ Restructuring stage } & $\begin{array}{c}\text { Without } \\
\text { using the } \\
\text { Law }\end{array}$ & $\begin{array}{c}\text { Using } \\
\text { the } \\
\text { Law }\end{array}$ \\
\hline 1 & Negatiations with creditors on restructuring & Yes & Yes \\
\hline 2 & Dbtaining the lender's consent to restructuring & Yes & Yes \\
\hline 3 & Preparation of documents for restructuring & Yes & Yes \\
\hline 4 & Financial documentation and calculations & Yes & Yes \\
\hline 5 & $\begin{array}{l}\text { Assessment of independent experts (assessment } \\
\text { of collateral, audit reports, etc.) }\end{array}$ & Yes & Yes \\
\hline 6 & Debtor Restructuring Plan Development & No & Yes \\
\hline 7 & $\begin{array}{l}\text { Preparation of an opinion on the viability of the } \\
\text { debtor by an independent expert }\end{array}$ & No & Yes \\
\hline 8 & Conducting the first meeting of creditors & No & Yes \\
\hline 9 & Lender Approval of the Restructuring Plan & No & Yes \\
\hline 10 & Signing a loan agreement & Yes & Yes \\
\hline
\end{tabular}

Note: compiled based on [14]

As the comparative analysis shows (Table 2), the differences were revealed related to the need to carry out such stages as the development of the debtor's restructuring plan, the preparation of an opinion by an independent expert on the debtor's viability, the first meeting of creditors, and the creditor's approval of the restructuring plan.

This approach makes the restructuring more balanced both from the position of the debtor and from the position of the creditor. The participation of an independent expert is important, who aims to find out the prospects of the debtor's activities in the context of the possibility of 
implementing the Restructuring Plan, which is the main goal of the restructuring procedure.

According to the amendments, banks with the participation of the state will be able to transfer bad debts to the DGFI management solely for its sale by this fund at an open auction (auction). The procedure for conducting such trades is regulated by the relevant normative acts of the fund [15].

Let's believe that the introduction of the requirements of European legislation into Ukrainian banking practice will contribute to strengthening the regulatory framework for the financial recovery of banks. This is due to the process of financial restructuring and provides for the creation of an appropriate by-law regulatory framework and its full implementation, which will contribute to the development of relations in the field of financial recovery of banks.

The measure of non-monetary state regulation of the financial recovery of banks within the framework of minimizing the credit risks of banks is the prevention of significant volumes of problem debts. Today, the key task of banks is to clear the balance sheets of non-performing loans. According to the recommendations of the International Monetary Fund (IMF), loans are considered invalid if the payment of the principal and interest on them is overdue:

1) for three months (90 days) or more;

2) for less than 90 days, however, in accordance with national supervisory standards, it is considered that the service of such a loan is «weak» or «unsatisfactory» [16].

At the same time, it is positive that the share of nonperforming loans in the loan portfolio of banks is decreasing. In addition, now banks have formed a sufficient level of reserves for such loans and continue to gradually and further reduce the share of bad debts on the balance sheet. Today the level of coverage of non-performing loans by their reserves is about $92-94 \%$ [10].

It should be noted that in order to minimize the credit risks of banks, the state regulator also introduced the requirements of European legislation for a unified approach to assessing the credit risk of securities [17]. This approach is based, in particular, on the credit ratings of the issuer/country of location of the issuer/securities, as determined by the international rating agencies Standard \& Poor's, Fitch Ratings and Moody's Investors Service. Also, the parameters of the logistic model and the ranges of values of the probability of default of debtors used by banks to assess their credit risk, taking into account updated market data, have been updated.

\section{Conclusions}

The study revealed that today banks have entered the period of a pandemic without noticeable imbalances, sufficiently capitalized and highly liquid. The work to clean up and increase the stability of the banking system, carried out since 2015, gave an indisputable positive result.

It is shown that an important strategic task of the regulator is the formation of an effective system of state regulation of banking activities. This is possible with the simultaneous use of both monetary and non-monetary methods in order to effectively use the potential of banks to ensure the stable functioning of the financial sector of the economy as a whole.

The results of the study will be useful for banks in the development of business models of their activities, the formation of strategies for financial recovery and diagnostics of bank insolvency. Interesting for the regulator to use there are proposals for taking into account international approaches to financial recovery in its regulatory activities.

Further studies, given the importance of preventing bank insolvency, will be associated with improving approaches to regulating banks' activities in the context of their financial recovery, taking into account the lessons of the current crisis.

\section{References}

1. Afanasieva, O. B. (2010). Zarubizhnyi dosvid antykryzovoho upravlinnia v bankakh. Problemy i perspektyoy rozoytku bankivskoi systemy Ukrainy, 29, 159-167.

2. Vovchak, O. D., Rudevska, V. I. (2018). Peculiarities of ensuring financial sustainability of the Ukrainian Banking System. Banks and Bank Systems, 13 (1), 184-195. doi: http://doi.org/ 10.21511/bbs.13(1).2018.17

3. Svitalkova, Z. (2014). Comparison and evaluation of bank efficiency in selected countries in EU. Procedia Economics and Finance, 12, 644-653. doi: http://doi.org/10.1016/S2212-5671(14)00389-X

4. Kornyliuk, R., Kornyliuk, A. (2018), Ukrainian Banks' Business Models Under Systemic Risk. CEUR Workshop Proceedings, 2105 , 124-138. Available at: http://ceur-ws.org/Vol-2105/10000124.pdf

5. Vovchak, O. D., Senyshch, P. M., Melnyk, T. V. (2019). «Purging» of the banking system: impacton the key performance indicators of banks. Financial and Credit Activity: Problems of Theory and Practice, 1 (28), 16-25. doi: http://doi.org/10.18371/fcaptp. v1i28.161886

6. Melnyk, T. V. (2017). Funktsionuvannia bankivskoi systemy Ukrainy v umovakh yii reformuvannia. Finansozyi prostir, 4 (28), 49-54. Available at: https://fp.cibs.ubs.edu.ua/index.php/fp/ article/view/536

7. Broeders, H., Khanna, S. (2015). Strategic choices for banks in the digital age. McKinsey\&Company. Available at: https:/ www.mckinsey.com/industries/financial-services/our-insights/ strategic-choices-for-banks-in-the-digital-age

8. Popov, V. L. (2008). Strategiia ozdorovleniia predpriiatiia. Perm: Iz-vo PGTU, 117.

9. Cherep, A. V., Romanchenko, O. O. (2010). The determination of measures for renewal the solvency of debtor. Visnyk Zaporizkoho natsionalnoho universytetu, 1 (5), 213-219.

10. Ofitsiinyi sait Natsionalnoho banku Ukrainy. Available at: https:// bank.gov.ua

11. Dani finansovoi zoitnosti bankiv Ukrainy. Available at: https:// bank.gov.ua/statistic

12. Fedorenko, M., Lychenko, O. (2019). Khto platyt za bankrutstvo bankiv? Yurydychna hazeta, 17-18 (671-672). Available at: http://yur-gazeta.com/publications/practice/bankivske-tafinansove-pravo/hto-platit-za-bankrutstvo-bankiv.html

13. Pro vnesennia zmin do deiakykh zakoniv Ukrainy shchodo vdoskonalennia protsedury provedennia finansovoi restrukturyzatsii (2019). Zakon Ukrainy No. 112-IX 19.09.2019. Available at: https://zakon.rada.gov.ua/laws/show/112-20

14. Kostetska, Yu. (2020). Spilne provedennia finansovoi restrukturyzatsii dlia kilkokh borzhnykiv: shcho $i$ yak. Available at: https:// yur-gazeta.com/publications/practice/bankivske-ta-finansovepravo/spilne-provedennya-finansovoyi-restrukturizaciyi-dlyakilkoh-borzhnikiv-shcho-i-yak.html

15. Pro vnesennia zmin do deiakykh zakonodavchykh aktiv Ukrainy shchodo vdoskonalennia systemy harantuvannia vkladiv fizychnykh osib ta vyvedennia neplatospromozhnykh bankiv z rynku (2019). Zakonoproiekt No. 2272 16.10.2019. Available at: http://w1.c1. rada.gov.ua/pls/zweb2/webproc4_1?pf3511=67099

16. Pro zatverdzhennia Polozhennia pro vyznachennia bankamy Ukrainy rozmiru kredytnoho ryzyku za aktyonymy bankivskymy operatsiiamy (2016). Postanova Pravlinnia NBU No. 351 30.06.2016. Available at: https://zakon.rada.gov.ua/laws/show/v0351500-16

17. Pro zatverdzhennia Polozhennia pro poriadok formuvannia ta vykorystannia bankamy Ukrainy rezerviv dlia vidshkoduvannia mozhlyoykh otrat za aktyonymy bankivskymy operatsiiamy (2012). Postanova Pravlinnia NBU No. 23 vid 25.01.2012. Available at: https://zakon.rada.gov.ua/laws/show/z0231-12

Roman Stadniychuk, Postgraduate Student, Banking University, Lviv Ukraine, e-mail: advokatsro@gmail.com, ORCID: http://orcid.org/ 0000-0002-5016-5685 